Research Article

Mutagenesis

\title{
FOXE1 polymorphisms and chronic exposure to nitrates in drinking water cause metabolic dysfunction, thyroid abnormalities, and genotoxic damage in women
}

\author{
Diana Dennys Gandarilla-Esparza ${ }^{1}$, Esperanza Yasmin Calleros-Rincón ${ }^{1}$, Hortensia Moreno Macias ${ }^{2}$, \\ María Fernanda González-Delgado, Gonzalo García Vargas ${ }^{3}$, Jaime Duarte Sustaita ${ }^{3}$, \\ Alberto González-Zamora ${ }^{4}$, Efraín Ríos-Sánchez ${ }^{1}$ and Rebeca Pérez-Morales ${ }^{1}$ (D) \\ ${ }^{1}$ Universidad Juárez del Estado de Durango, Facultad de Ciencias Químicas, Laboratorio de Biología \\ Celular y Molecular, Gómez Palacio, Durango, México. \\ ${ }^{2}$ Universidad Autónoma Metropolitana, División CSH de la Unidad Iztapalapa, Departamento \\ de Economía, Vicentina, Ciudad de México, México. \\ ${ }^{3}$ Universidad Juárez del Estado de Durango, Facultad de Ciencias de la Salud, Departamento \\ de Investigación. Gómez Palacio, Durango, México. \\ ${ }^{4}$ Universidad Juárez del Estado de Durango, Facultad de Ciencias Biológicas, Laboratorio \\ de Biología Evolutiva, Gómez Palacio, Durango, México.
}

\begin{abstract}
Nitrates in drinking water has been associated to adverse health effects, including changes in glucose and lipid levels, thyroid hormone imbalance and adverse reproductive effects. We analyzed metabolic and thyroid hormone alterations and genotoxic damage in women with chronic exposure to nitrates in drinking water. The concentration of nitrates in drinking water was quantified and according to this parameter, participants were divided into three exposure scenarios. Blood and urine samples were collected from 420 women living in Durango, Mexico and biomarkers were determined. We found nitrates concentrations in drinking water above the permissible limit $(>50 \mathrm{mg} / \mathrm{L})$, and an increase in the percentage of methemoglobin $(p=0.0001)$, nitrite in blood plasma and urine $(p=0.0001)$, glucose $(p=0.0001)$, total cholesterol $(p=0.001)$, LDL $(p=0.001)$ and triglycerides $(p=0.0001)$. We also found alterations in TSH $(p=0.01)$, fT3 $(p=0.0003)$, T4T $(p=0.01)$ and fT4 $(p=0.0004)$ hormones. Frequency of subclinical hypothyroidism was 8.33\%; differences in FOXE1 (rs965513, rs 1867277) genotypes distribution were found and both polymorphisms were associated with a decrease in TSH. A high percentage of micronucleus in binucleate lymphocyte cells was found $(35 \%, p=0.0001)$. In conclusion, the chronic exposure to nitrates in water for human consumption caused metabolic and hormonal alterations and genotoxic damage in women.
\end{abstract}

Keywords: FOXE1 polymorphisms, nitrate exposure; subclinical hypothyroidism; methemoglobin; genotoxic damage.

Received: January 22, 2021; Accepted: June 30, 2021.

\section{Introduction}

Nitrate is a natural compound present in soil, air and water, which forms part of the nitrogen cycle. Nitrogen and its stable forms are essential components of many molecules; however, it is also considered a potential health hazard due to the generation of $\mathrm{N}$-nitroso compounds, which are prooxidants of several biomolecules. The pollution caused by nitrates is mainly attributed to certain industrial activities, as well as to the use of fertilizers in agriculture. Intake of nitrates among the human population occurs mainly through consumption of vegetables and processed foods, in addition to contaminated water. Water contamination occurs through leaching due the excessive use of fertilizers and pesticides that pollute the soil, which later reach the aquifers, contaminating

Send correspondence to Rebeca Pérez-Morales. Universidad Juárez del Estado de Durango, Facultad de Ciencias Químicas, Laboratorio de Biología Celular y Molecular, Av. Artículo, 123, Fracc., Filadelfia, C.P. 35010. Gómez Palacio, Durango, México. E-mail: rebecapms @ ujed. $\mathrm{mx}$ the water that supplies the network for public use (Ombreta et al., 2018).

The Mexican Official Guidelines (NOM-127-SSA-11994) (http://www.salud.gob.mx/unidades/cdi/nom/127ssa14. $\mathrm{html}$ ) established a maximum permissible limit of nitrates for human use and consumption of up to $44.3 \mathrm{mg} / \mathrm{L}(10 \mathrm{mg} / \mathrm{L}$ Nitrate-Nitrogen), consistent with the limit specified by the US Environmental Protection Agency (EPA). The World Health Organization (WHO) set a recommended limit of 50 $\mathrm{mg} / \mathrm{L}$ (11.3 mg/L of Nitrate-Nitrogen) (http://www.who.int/ water_sanitation_health/water-quality/guidelines/en/).

Upon ingestion, nitrate begins its transformation in the oral cavity by nitrate-reducing bacteria (nitrate reductases enzymes), which convert nitrate to nitrite. It is then absorbed in the small intestine by active transport, and another fraction is biotransformed by the microbiota and the acidic environment of the gastrointestinal tract, while nitrite is absorbed by diffusion across the gastric mucosa and gut wall. Approximately $5 \%$ of the nitrate ingested is reduced to nitrite by reducing bacteria present in the oral cavity, and around $25 \%$ is partially recycled 
in the salivary glands that concentrate the nitrate from the plasma, which is again reduced to $\mathrm{NO}_{2}$. After absorption, around $60 \%$ of nitrate is excreted in the urine, $3 \%$ is excreted in the form of urea or ammonium (Karwowska and Kononiuk, 2020).

During the biotransformation of nitrate, reactive nitrogen species (RNS) are generated; these are potent carcinogens for both animals and humans. The RNS generated through the nitrates metabolism include nitric dioxide, nitric oxide (NO), and peroxynitrite. These RNS can generate oxidative stress capable of damaging DNA, proteins, lipids and cell tissues, and can even compromise the function of organs such as the liver and the intragastric mucosa (Rocha et al., 2012). This compromised liver function is due to the activity of cytochrome P450 present in hepatic microsomes, which can generate nitrosamines and other compounds that are more reactive than the initial RNS (DeMartino et al., 2019). In vitro studies have been conducted to determine genotoxic damage from exposure to nitrate; these studies reported a higher frequency of micronuclei in individuals treated with potassium nitrate and sodium nitrate (Stivaktakis et al., 2010).

Nitrate is less toxic than nitrite because it causes the oxidation of hemoglobin to methemoglobin (metHb). Hemoglobin is responsible for the transport of oxygen through blood vessels and capillaries, while metHb is not able to release oxygen; therefore, nitrite can cause hypoxia that in severe cases may be able to cause death (Johnson et al., 1987). The consumption of water contaminated by nitrate has been associated with an increased percentage of metHb and nitrate metabolites, such as NO, which have physiological and pathophysiological effects on inflammation, vasodilation and metabolism. In other studies, it has been reported that a high NO production, possibly derived from the biotransformation of ingested nitrate, is associated with hyperlipidemia, affecting total cholesterol, high-density lipoprotein (HDL) and lowdensity lipoprotein (LDL) cholesterol serum concentrations; while other studies are inconclusive for whether there is an association between exposure to nitrates and serum glucose levels (Lundberg et al., 2018).

On the other hand, the thyroid gland can concentrate monovalent anions such as nitrates, leading to altered homeostasis by inhibiting the uptake of iodine, which is essential for the structure and formation of thyroid hormones. Iodine is transported by sodium/iodide Symporter (NIS), which are located in the intestine, mammary, salivary and thyroid gland and placenta (Hallinger et al., 2017). Some studies have reported that nitrates, thiocyanate and perchlorate inhibit the uptake of iodine, leading to various alterations in the levels of thyroid hormones T3 (triiodothyronine) and T4 (thyroxine), along with increased thyroid-stimulating hormone (TSH) levels (Cengiz and Bilgin, 2016). Several studies have linked the consumption of drinking water and foods high in nitrates with hypothyroidism and thyroid cancer; however, the associations are inconclusive (Donoso and Cortés, 2018).

In addition, polymorphisms in genes involved in the synthesis of thyroid hormones can also affect the circulating levels of these hormones. FOXE1 is a transcription factor involved in the migration of thyroid precursors during the morphogenesis of the gland and subsequent cell differentiation. Polymorphisms in the FOXE1 gene have been associated with thyroidism, increased risk of papillary thyroid cancer and sporadic follicular thyroid tumors. (Mendieta-Zerón et al., 2017; Chen and Zhang, 2018). Mutations in this gene cause Bamforth syndrome (hypothyroidism and palate abnormalities), demonstrating the importance of FOXE1 protein in the development and differentiation of the thyroid gland. Studies carried out in European populations have shown a significant association of the FOXE1 rs965513 polymorphism with altered levels of TSH, free T3 (fT3) and free T4 (fT4) (Gudmundsson et al., 2009).

In Mexico, the Comarca Lagunera is a region known for its extensive industrial and mining activities; as a result, the water can be contaminated with nitrates and other compounds discarded by industry. This region is the main dairy basin of northern Mexico and, consequently, there is an excessive demand to produce fodder for livestock; this has led to the indiscriminate use of pesticides and fertilizers. In addition, cattle generate a large amount of manure. The nitrogenous compounds in manure are converted to nitrates, and eventually reach water supply wells used for consumption by local communities. Therefore, the population is chronically exposed to nitrates in drinking water. In rural areas there is a high migration rate of men, therefore the population with the highest exposure are women. The aim of this study was to analyze the exposure, effect and genetic biomarkers in women with chronic exposure to nitrates in drinking water.

\section{Materials and Methods}

\section{Quantification of nitrates in drinking water (wells and home)}

The water collection was carried out in the period from March 2015 to December 2017. Eight communities that are supplied by the Ciudad Juárez aquifer (La Loma, Sapioriz, Ciudad Juarez, Juan E. García, Nazareno, 21 de marzo and San Jacinto) were selected for measurement of the nitrate concentration in water for human consumption. Water samples from wells $(100 \mathrm{~mL})$ were collected following the recommendations of the Mexican Official Guideline (NOM-127-SSA-1-1994), that establishes the permissible limits of quality and treatments that water must be submitted to, for its purification and use for human consumption. Water samples were also collected from randomly selected households located within approximately $100 \mathrm{~m}$ from the well that supplies the drinking water network. Determination of nitrates concentration in water samples was carried out using the selective electrode ion method with a Hoviba BW74 potentiometer. To perform the measurement, a calibration curve for potassium nitrate was generated, with a detection limit between $1 \mathrm{mg} / \mathrm{L}$ to $60 \mathrm{mg} / \mathrm{L}$ Nitrate-Nitrogen. Conversion was performed to express the results as nitrate ion.

\section{Study population}

A cross-sectional descriptive observational study was carried out, the sampling was carried out in the period from March 2015 to December 2017. In the health centers of each community, an open call was made to invite women between 18 and 45 years old to answer a questionnaire to document general epidemiological and lifestyle data. The women had 
to meet the following inclusion criteria be residents of the study communities for longer than 3 years, consume water mainly from the tap or well and not to be pregnant. The study included 420 women from rural communities in the municipality of Lerdo, Durango, Mexico (21 de marzo, Sapioriz, Ciudad Juarez, San Jacinto, Juan E. García, La Loma and Nazareno). The study was approved by the Ethics Committee of the Facultad de Ciencias Químicas of the Universidad Juárez del Estado de Durango (registration number R-2014-123301538X0201-012). The study was performed under an ethical agreement and maintained individual anonymity; informed consent was obtained from each participant. The participants answered a structured questionnaire which provided information on education level, occupation, diet, personal and family pathological histories, as well as environmental and occupational exposure.

\section{Biological sampling}

Peripheral blood samples (BD Vacutainer ${ }^{\circledR}$ serum $6 \mathrm{~mL}, \mathrm{BD}$ Vacutainer ${ }^{\circledR}$ EDTA $4 \mathrm{~mL}$ and BD Vacutainer ${ }^{\circledR}$ lithium heparin $6 \mathrm{~mL}$ ) and a urine sample were collected from each participant. The serum was obtained and stored at $-70^{\circ} \mathrm{C}$ until processing biochemical parameters and thyroid hormone analyzes. Blood samples collected into the tube containing EDTA were used to measure nitrite in plasma and metHb percentage, also for DNA purification to determine FOXE1 polymorphisms. Peripheral blood collected into the tube containing lithium heparin was used for the cytokinesisblock micronucleus cytome assay in lymphocytes. The first morning urine sample was used for nitrite determination, as an indirect biomarker of nitrate. The sample was collected in a sterile vial and stored at $-70^{\circ} \mathrm{C}$ until processing.

\section{Nitrite concentration in plasma and urine}

The concentrations of nitrite in plasma and urine samples were determined by the Griess colorimetric method, previously reported (Moshage et al., 1995) using spectrophotometric quantification at $540 \mathrm{~nm}$. As a reference, a curve with sodium nitrite and detection limit between $0.5-30 \mu \mathrm{mol} / \mathrm{mL}$ was performed in triplicate and each sample was measured by duplicate. All reagents used were high purity (Sigma-Aldrich Darmstadt, Germany).

\section{Methemoglobin percentage}

The metHb percentage was measured using the method reported by Sakata et al. (1982). Each sample was measured by duplicate. All reagents used were high purity (Sigma-Aldrich Darmstadt, Germany).

\section{Biochemical parameters}

The biochemical parameters assessed included glucose, triglycerides, total cholesterol and HDL cholesterol which were determined following the manufacturer's instructions (Pointe Scientific Brussels, Belgium). The LDL cholesterol concentration was calculated using the equation reported previously (Friedewald et al., 1972). The limits of the reagents were as follows: glucose, $0-500 \mathrm{mg} / \mathrm{dL}$; cholesterol, 0-700 $\mathrm{mg} / \mathrm{dL}$; and triglycerides, $0-1000 \mathrm{mg} / \mathrm{dL}$. The concentrations of each parameter were expressed as milligrams per deciliter.

\section{Thyroid-stimulating hormone, total and free T3 and T4 determinations}

The quantification of thyroid hormones (TSH, total T3, fT3, total T4 and fT4) was performed by chemiluminescence immunoassays (Immulite ${ }^{\circledR} 1000$ Siemens Gwynedd, United Kingdom). The TSH assay had a sensitivity of $0.004 \mu \mathrm{IU} /$ $\mathrm{mL}$ and an upper limit of $75 \mu \mathrm{IU} / \mathrm{mL}$. The reference ranges for thyroid hormones were TSH, $0.4-4.0 \mu \mathrm{IU} / \mathrm{mL}$; total T3, 82-179 ng/dL; fT3, 1-40 pg/mL; total T4, 4.5-12.5 $\mu \mathrm{g} / \mathrm{dL}$; and fT4, 0.3-6.0 ng/dL.

\section{rs965513 and rs1867277 genotyping in FOXE1}

DNA was extracted from peripheral blood leukocytes by the standard CTAB-DTAB (Sigma-Aldrich Darmstadt, Germany) method. Two variants of the FOXE1 gene were analyzed by real-time PCR in a Step One (Applied Biosystems, Foster City, California, USA) device using pre-designed TaqMan assays for rs965513 (C_1593670) and rs1867277 (C_11736668) (Applied Biosystems, Foster City, California, USA). The PCR assay was carried out according to the standard protocol recommended by the manufacturer.

\section{Cytokinesis-block micronucleus cytome assay in lymphocytes}

Genotoxic damage was evaluated by a cytokinesis-block micronucleus cytome assay (Fenech, 2007). Following the culture of peripheral blood with the addition of $\beta$-cytochalasin, the preparations were stained with $5 \%$ Giemsa stain for microscopic observation. A count of 1,000 cells per individual was carried out, as suggested by the International Micronucleus Consortium; considering all binucleated cells with micronuclei, mononuclear, trinucleated and tetranucleated cells, cells with nucleoplasmic bridges and bubble protrusions, and those in necrosis and apoptosis. The proliferation index was calculated for each individual experiment. All reagents used were high purity or cell culture grade (Sigma-Aldrich Darmstadt, Germany).

\section{Statistical analyses}

Nitrate levels in drinking water for each community were used to classify exposure as low, medium or high, based on other studies reported and the maximum permissible limit for human consumption of $50 \mathrm{mg} / \mathrm{L}$. Data are presented as mean \pm standard derivation, the variables that did not show a normal distribution are reported as median and Q1-Q3 values. To determine differences between exposure groups, Kruskal-Wallis and Dunn's tests were applied, or a Chi-square test, depending on the variable. To determine the association between biomarkers and levels of exposure a multiple linear regression was used, adjusting for age, body mass index (BMI), consumption of alcoholic drinks, tobacco, education level and diet. All statistical analyses were performed using the STATA version 13 for Windows software package and a $\mathrm{P}$ value $<0.05$ was considered statistically significant. 


\section{Results}

\section{Nitrate levels in water for human consumption in the studied communities}

The general characteristics of the studied populations and nitrates concentration in water for human consumption are presented in Table 1. An increase in the concentrations reported in 2012 and 2014 was observed, with respect to the data obtained in this study. Participants were stratified in three groups according to the nitrate concentration determined in drinking water. Although there is a distinction between low, medium and high exposure, there is no consensus about the ranges and doses in each group, a strategy is to stratify according to the concentrations found in the specific study, in order to observe the exposure gradient. The average concentration of nitrates of all samples collected from wells and households were $4.7 \pm 3.3,32.1 \pm 3.7$ and $56.9 \pm 14.7$ $\mathrm{mg} / \mathrm{L}$ of nitrates from low, medium and high exposure groups, respectively. Some of these values were higher than the 44.3-50 $\mathrm{mg} / \mathrm{L}$ permissible limit of nitrates established by NOM-127SSA-1-1994 and WHO (2011). The water consumption from de local network was estimated with a standardized measure ( $250 \mathrm{~mL}$ container), from this, the amount of water they drink daily was calculated. The mean values were $2.08 \pm 1.03$, $1.91 \pm 0.82$ and $2.4 \pm 0.95 \mathrm{~L}$ for the low, medium and high exposure groups, respectively.

\section{General characteristics of the study population}

This study evaluated 420 women, of whom 139 were exposed to low levels, $171 \mathrm{had}$ a medium exposure and 110 were exposed to high levels of nitrates in drinking water. For all women, the median age was 36 years (32-40 years) and median BMI was 28 (25-32). In all groups, more than $30 \%$ of the individuals were overweight or obese; over $85.5 \%$ of the participants had a basic education (primary to secondary schooling), and the predominant occupation was housewife ( $95 \%)$. Consumption of tap water was reported to be around $80 \%$ of all beverages, with some participants reporting infrequent consumption of bottled water from water purifying machines (purified by reverse osmosis). Consumption of alcoholic beverages was low (13.6\%), and cigarette smoking (6.7\%) was not frequent at either exposure level (Table 1). In addition, the diet of the study population was based on processed meat (bacon $2.8 \%$, sausage $11 \%$ and ham $7 \%$ ), vegetables (spinach $2.4 \%$, cabbage $7 \%$, lettuce $12 \%$, carrots $13 \%$, cucumber $9 \%$, broccoli $4.8 \%$, pepper $65 \%$, tomato $68 \%$ ) and fruits (orange $38 \%$, lemon $29 \%$, watermelon $9 \%$ ), but there are no differences in consumption among groups.

\section{Alterations in biochemical parameters}

The nitrite concentration was determined in plasma and urine samples and we observed a dose dependent increase $(p=0.001)$. The percentage of metHb showed a dose dependent

Table 1 - Level of exposure to nitrates across time and general characteristic of the study population by communities.

\begin{tabular}{|c|c|c|c|c|c|}
\hline \multicolumn{6}{|c|}{ Levels of Nitrate $\mathrm{mg} / \mathrm{L}$ by years $(\mu \pm \mathrm{SD})$} \\
\hline Communities & & $\begin{array}{l}21 \text { marzo } \\
\text { Sapioriz } \\
\text { Cd. Juárez }\end{array}$ & $\begin{array}{l}\text { San Jacinto } \\
\text { Juan E. García, }\end{array}$ & $\begin{array}{l}\text { La Loma } \\
\text { Nazareno }\end{array}$ & \\
\hline $2010-2012^{£}$ & & 3.2 & 18.14 & 36.5 & \\
\hline $2013-2014^{¥}$ & & $3.8 \pm 3.2$ & $24.1 \pm 3.2$ & $47.6 \pm 7$ & \\
\hline $2015-2017^{\S}$ & & $4.7 \pm 3.3$ & $32.1 \pm 3.7$ & $56.9 \pm 14.7$ & \\
\hline $\begin{array}{l}\text { Daily consumption of drinking } \\
\text { water }(L)(\mu \pm S D)\end{array}$ & & $2.08 \pm 1.03$ & $1.91 \pm 0.82$ & $2.4 \pm 0.95$ & \\
\hline Parameter & $\begin{array}{l}\text { All women } \\
\mathbf{n}=\mathbf{4 2 0}\end{array}$ & $\begin{array}{c}\text { Low level } \\
n=139\end{array}$ & $\begin{array}{l}\text { Medium level } \\
n=171\end{array}$ & $\begin{array}{l}\text { High level } \\
\mathbf{n}=110\end{array}$ & P-value \\
\hline Age (years) & $36(32-40)$ & $36(33-40)$ & $35(30-41)$ & $37(33-40)$ & $0.4023^{*}$ \\
\hline $\begin{array}{l}\text { BMI }\left(\mathrm{kg} / \mathrm{m}^{2}\right) \\
<24.9 \\
25-29.9 \\
\geq 30\end{array}$ & $\begin{array}{c}28.5(25.5-32.4) \\
88(21 \%) \\
173(41 \%) \\
159(38 \%)\end{array}$ & $\begin{array}{c}29.3(26.5-32.9) \\
17(12 \%) \\
62(45 \%) \\
60(43 \%)\end{array}$ & $\begin{array}{c}28.5(24.7-33.3)^{\mathrm{a}} \\
45(26 \%) \\
56(33 \%) \\
70(41 \%)\end{array}$ & $\begin{array}{c}27.9(25.3-30)^{b} \\
26(24 \%) \\
55(50 \%) \\
29(26 \%)\end{array}$ & $\begin{array}{l}0.0433^{*} \\
0.006^{\text {** }} \\
0.018^{\text {** }} \\
0.041^{\text {** }}\end{array}$ \\
\hline $\begin{array}{l}\text { Education } \\
<\text { high school } \\
>\text { high school }\end{array}$ & $\begin{array}{l}359(85 \%) \\
61(15 \%)\end{array}$ & $\begin{array}{l}125(90 \%) \\
14(10 \%)\end{array}$ & $\begin{array}{l}135(79 \%) \\
36(21 \%)\end{array}$ & $\begin{array}{l}99(90 \%) \\
11(10 \%)\end{array}$ & $0.007^{* *}$ \\
\hline $\begin{array}{l}\text { Occupation } \\
\text { Homemaker } \\
\text { Seasonal agriculture }\end{array}$ & $\begin{array}{c}399(95 \%) \\
21(5 \%)\end{array}$ & $\begin{array}{l}132(95 \%) \\
7(5 \%)\end{array}$ & $\begin{array}{c}159(93 \%) \\
12(7 \%)\end{array}$ & $\begin{array}{c}106(97 \%) \\
4(3 \%)\end{array}$ & $0.40 * *$ \\
\hline $\begin{array}{l}\text { Drinking water } \\
\text { Well } \\
\text { Purified }\end{array}$ & $\begin{array}{l}335(80 \%) \\
85(20 \%)\end{array}$ & $\begin{array}{l}118(85 \%) \\
21(15 \%)\end{array}$ & $\begin{array}{l}124(73 \%) \\
47(27 \%)\end{array}$ & $\begin{array}{l}93(85 \%) \\
17(15 \%)\end{array}$ & $0.009^{* *}$ \\
\hline Smoking current & $28(6 \%)$ & $11(7 \%)$ & $14(8 \%)$ & $3(2 \%)$ & $0.138^{* *}$ \\
\hline Alcohol consumption & $57(13 \%)$ & $18(12 \%)$ & $28(16 \%)$ & $11(10 \%)$ & $0.293^{* *}$ \\
\hline
\end{tabular}

${ }^{£}$ Data from Calleros et al., 2012, ${ }^{\sharp}$ Data from Conagua, ${ }^{\S}$ Levels measured in this study

Age and BMI (body mass index) are showed as median (Quantile 1 - Quantile 3). Stratifying of BMI, education, occupation, drinking water, smoking current and alcohol consumption are showed as $\mathrm{n}(\%)$. Purified water by inverse osmosis method.

P-value correspond to Kruskal Wallis test $\left({ }^{*}\right)$ and Chi squared test $\left({ }^{* *}\right)$, while Dunn's test is showed with superscript letter: exposure: a low-medium, b exposure low-high. 
increase $(\mathrm{p}=0.001)$. The correlation between the doses of nitrate and the percentage of methemoglobin was Spearman $=0.25$ $(p=0.0001)$, while the correlation between the doses of nitrate and concentration of circulating nitrite in the plasma was Spearman $=0.29(p=0.0001)$ and the correlation between percentage of methemoglobin and concentration of circulating nitrite in the plasma was Spearman $=0.18(\mathrm{p}=0.0001)$. Finally, the correlation between concentration of circulating nitrite in the plasma and concentration of circulating nitrite in the urine was Spearman $=0.38(\mathrm{p}=0.0001)$.

Among the biochemical parameters tested, the serum glucose level was increased in the high exposure group (103.2 $\mathrm{mg} / \mathrm{dL}, \mathrm{p}=0.001$ ), while for the lipids, the concentration of cholesterol increased in the medium and high exposure groups (175.1 and $179.85 \mathrm{mg} / \mathrm{dL}$, respectively, $\mathrm{p}=0.0012$ ); HDL cholesterol decreased in the medium exposure group (49.4 mg/dL, $\mathrm{p}=0.06)$ and LDL cholesterol increased in the medium exposure group $(98 \mathrm{mg} / \mathrm{dL}, \mathrm{p}=0.001)$. Finally, for triglycerides the high exposure group showed the highest levels $(127.7 \mathrm{mg} / \mathrm{dL}, \mathrm{p}=0.001)$; although these were within the reference limits (Table 2).

\section{Alterations in the thyroid hormonal profile and effect of FOXE1 polymorphisms}

The serum concentrations of thyroid hormones are presented in Table 3. The TSH medians (Q1-Q3) were 1.63 (1.18-2.42), 2.02 (1.3-3.01), $1.6(1.17-2.49) \mu \mathrm{IU} / \mathrm{mL}$ from low, medium and high exposure groups $(\mathrm{p}=0.01)$, respectively. Differences were found in the levels of fT3 $(p=0.0003), T 4 T$ $(p=0.01)$ and $\mathrm{fT} 4(\mathrm{p}=0.0004)$ in the medium and high exposure groups; while the frequency of subclinical hypothyroidism (SH) did not show significant variation between groups $(\mathrm{p}=0.2)$. As mentioned above, FOXE1 gene polymorphisms may cause a high risk to thyroid disorders. In the study population, the rs965513 SNP had an allelic frequency of 0.25 to polymorphic allele (A) (gMAF=0.21), and the rs1867277 SNP was found with an allelic frequency of 0.30 to polymorphic allele (A) ( $\mathrm{gMAF}=0.31$ ). Both polymorphisms were in Hardy-Weinberg equilibrium. A stratified analysis by exposure group was performed and significant differences were found in the genotypic frequencies of the rs965513 SNP and the rs 1867277 SNP (Table 4). A decrease in TSH levels was also found when the polymorphic allele was in heterozygous or homozygous

Table 2 - Biochemical parameters in women exposed to nitrates in drinking water.

\begin{tabular}{|c|c|c|c|c|c|c|c|}
\hline Parameters & $\begin{array}{l}\text { All women } \\
n=420\end{array}$ & $\begin{array}{c}\text { Low } \\
\mathrm{n}=139\end{array}$ & $\begin{array}{c}\text { Medium } \\
\mathrm{n}=171\end{array}$ & $\begin{array}{l}\text { High } \\
\mathrm{n}=110\end{array}$ & $\begin{array}{l}\text { Reference } \\
\text { rank }\end{array}$ & $\begin{array}{l}\% \text { out } \\
\text { of rank }\end{array}$ & $\mathrm{P}$-value \\
\hline $\begin{array}{l}\text { Nitrite } \mu \mathrm{mol} / \mathrm{mL} \\
\text { blood }\end{array}$ & $\begin{array}{c}10.37(5.72- \\
24.17)\end{array}$ & $\begin{array}{c}7.18(4.94- \\
11.87)\end{array}$ & $\begin{array}{c}9.15(6.18- \\
23.99)^{\mathrm{a}}\end{array}$ & $\begin{array}{c}24.35(12.05- \\
38.45)^{\mathrm{b}, \mathrm{c}}\end{array}$ & & & $0.0001 *$ \\
\hline $\begin{array}{l}\text { Nitrite } \mu \mathrm{mol} / \mathrm{mL} \\
\text { urine }\end{array}$ & $4.09(1.05-7.84)$ & $2.4(0.89-4.85)$ & $\begin{array}{c}4.45(0.64- \\
9.52)^{\mathrm{a}}\end{array}$ & $\begin{array}{l}5.72(3.91- \\
8.79)^{\mathrm{b}}\end{array}$ & & & $0.0001 *$ \\
\hline$\%$ methemoglobin & $1.94(1.16-2.53)$ & $1.33(0.9-2)$ & $1.56(1.1-2.08)^{\mathrm{a}}$ & $2.7(2.5-2.9)^{\mathrm{b}, \mathrm{c}}$ & $<1.5$ & 80.71 & $0.0001 *$ \\
\hline Glucose mg/dL & $\begin{array}{c}90.35(79.6- \\
108.15)\end{array}$ & $86.2(75.2-100)$ & $88.6(79.8-101)$ & $\begin{array}{c}103.2(84.2- \\
132)^{\mathrm{b}, \mathrm{c}}\end{array}$ & $70-110$ & 30.94 & $0.0001 *$ \\
\hline Cholesterol mg/dL & $\begin{array}{c}164.85(133.5- \\
208.2)\end{array}$ & $151(131-178.5)$ & $\begin{array}{c}175.1(133.5- \\
208.6)^{\mathrm{a}}\end{array}$ & $\begin{array}{c}179.85(136.4- \\
225.8)^{\mathrm{b}, \mathrm{c}}\end{array}$ & $<200$ & 29.29 & $0.0012 *$ \\
\hline HDL mg/dL & $52.2(40.4-71)$ & $58.3(41.5-73)$ & $\begin{array}{c}49.4(38.5- \\
68.6)^{\mathrm{a}}\end{array}$ & $51.1(41-69.4)$ & $30-75$ & 20.15 & 0.0684 \\
\hline LDL mg/dL & $92(74.5-132)$ & 82.5 (66.4-104) & $98(79-135)^{\mathrm{a}}$ & $96(80-144)^{b}$ & $<130$ & 40.95 & $0.001 *$ \\
\hline Triglyceride mg/dL & $\begin{array}{c}104.4(73.5- \\
145.2)\end{array}$ & $\begin{array}{c}101.8(67.1- \\
131.2)\end{array}$ & $90.1(69.7-134)$ & $\begin{array}{c}127.7(96- \\
172.4)^{\mathrm{b}}\end{array}$ & $<150$ & 23.57 & $0.0001^{*}$ \\
\hline
\end{tabular}

The data are showed as median (Quantile 1- Quantile 3).

P-value correspond to Kruskal Wallis test. * Significant differences

Significant differences in Dunn's test $(\mathrm{p}<0.05)$ : ${ }^{\text {e }}$ exposure low-medium, ${ }^{\mathrm{b}}$ exposure low-high, ${ }^{\mathrm{c}}$ exposure medium-high

Table 3 - Levels of thyroid hormones in women exposed to nitrates in drinking water.

\begin{tabular}{|c|c|c|c|c|c|c|}
\hline Parameters & $\begin{array}{c}\text { All women } \\
n=420\end{array}$ & $\begin{array}{c}\text { Low } \\
\mathrm{n}=139\end{array}$ & $\begin{array}{c}\text { Medium } \\
\mathrm{n}=171\end{array}$ & $\begin{array}{l}\text { High } \\
\mathrm{n}=110\end{array}$ & Reference rank & P-value \\
\hline $\mathrm{TSH} \mu \mathrm{UI} / \mathrm{mL}$ & $1.74(1.24-2.67)$ & $1.63(1.18-2.42)$ & $2.02(1.3-3.01)^{\mathrm{a}}$ & $1.6(1.17-2.49)^{\mathrm{c}}$ & $0.4-4$ & $0.0126^{*}$ \\
\hline T3T ng/dL & 113 (98.1-132) & $110(95.4-128)$ & $115(99-140)^{\mathrm{a}}$ & $113(100-128)$ & $82-179$ & 0.1564 \\
\hline $\mathrm{fT} 3 \mathrm{pg} / \mathrm{mL}$ & $3.48(3.07-4.05)$ & $3.49(3.17-3.92)$ & $3.59(3.07-4.63)^{\mathrm{a}}$ & $\begin{array}{c}3.31(3.05-3.67) \\
\text { b,c }\end{array}$ & $1-4$ & $0.0003 *$ \\
\hline $\mathrm{T} 4 \mathrm{~T} \mu \mathrm{g} / \mathrm{dL}$ & $7.7(6.8-8.65)$ & $7.85(7.06-8.97)$ & $7.46(6.55-8.62)^{\mathrm{a}}$ & $7.5(6.8-8.32)^{c}$ & $4.5-12.5$ & $0.0186^{*}$ \\
\hline $\mathrm{fT} 4 \mathrm{ng} / \mathrm{dL}$ & $1.07(0.97-1.17)$ & $1.08(1-1.19)$ & $1.03(0.94-1.13)^{\mathrm{a}}$ & $1.11(0.99-1.2)^{\mathrm{c}}$ & $0.3-6$ & $0.0004^{*}$ \\
\hline Subclinical hypothyroidism & $35(8.33)$ & $10(7.19)$ & $19(11.11)$ & $6(5.45)$ & & $0.206 \S$ \\
\hline
\end{tabular}

The data are showed in median (Quantile 1 - Quantile 3).

P value correspond to Kruskal Wallis test. *Significant difference. Significant differences in Dunn's test (p<0.05): ${ }^{a}$ exposure low-medium, ${ }^{b}$ exposure low-high, ${ }^{\mathrm{c}}$ exposure medium-high.

Subclinical hypothyroidism was considered if TSH $>4 \mu \mathrm{UI} / \mathrm{mL}, \mathrm{n}(\%)$ are showed. $\S$ Chi squared test. 
condition, the behavior was the same for both SNPs: rs965513 $(\mathrm{p}=0.0001)$ and $\mathrm{rs} 1867277(\mathrm{p}=0.005)$ (Figure 1).

\section{Genotoxic damage in women with chronic exposure to nitrates}

Nitrate generates RNS during its biotransformation, so in this study we evaluated the genotoxic damage present in the lymphocytes of women chronically exposed to nitrates in drinking water. The cytokinesis-block micronucleus assay was used because the cells are stimulated to enter the cell cycle and manifest damage that had not yet been observed in $\mathrm{G} 0$ cells. This is a technique validated by the international micronucleus consortium that allows the analysis of multiple alterations, including necrosis and apoptosis, it is also considered a cancer risk marker. In this respect, the presence of binucleated cells with micronuclei increased in the groups with medium $(41.8 \%)$ and high level of exposure $(42.6 \%), p=0.0001$. These values exceed the established normal range (0-30\%). Also, the number of binucleated cells with nucleoplasmic bridges and binucleated cells with bubble protrusions exceeded the normal range. Differences were significant among groups: $\mathrm{p}=0.03$ and $\mathrm{p}=0.002$, respectively (Table 5).

\section{Multivariable analysis of the association between biomarkers and concentration of nitrates in drinking water}

Alterations in some biochemical and thyroid parameters were observed in the population exposed to medium and high concentrations of nitrates, therefore, a multiple regression analysis was carried out to determine the strength and magnitude of the associations. In the model, it was observed that high levels of exposure to nitrate through drinking water predicted an increase in TSH levels ( $\beta$ coefficient $=0.21, p=0.007$ ) and these were negatively influenced by the polymorphic allele of the rs965513 SNP (GA: $\beta$ coefficient $=-0.17, p=0.01, \mathrm{AA}: \beta$ coefficient $=-0.4, p=0.002)$. Also, an increase in the levels of
$\mathrm{T} 3(\beta$ coefficient $=0.07, \mathrm{p}=0.008)$ and $\mathrm{fT} 3(\beta$ coefficient $=0.12$, $\mathrm{p}=0.0001)$ was observed; as well as a decrease of T4 ( $\beta$ coefficient $=-0.07, \mathrm{p}=0.008$ ), in the medium exposure group. In addition, significant changes were observed in the levels of nitrite in urine, as well as in the levels of glucose, total cholesterol, HDL cholesterol and triglycerides (Table 6).

\section{Discussion}

The concentration of nitrates present in the study area has increased in recent years. Previously, we reported levels between $3.2-36.5 \mathrm{mg} / \mathrm{L}$ of nitrate in 2010-2012 (Calleros Rincón et al., 2012), while measurements from the National Water Commission (CONAGUA, by its acronym in Spanish), in Durango region, Mexico, reported levels between 3.8-47.6 $\mathrm{mg} / \mathrm{L}$ of nitrates in 2013-2014 (https://sigagis.conagua.gob. $\mathrm{mx} /$ gas 1/sections/Edos/durango/durango.html). For the current study we found levels ranging from $4.7-56.9 \mathrm{mg} / \mathrm{L}$ of nitrates in water for human consumption. All the data correspond to the same aquifer, indicating that there has been an increase in nitrate concentrations over the years. The increase in nitrate concentrations observed may be due to several factors, including agricultural overproduction, the lack of maintenance of the water supply network and the presence of other physical and biological factors.

The nitrate concentrations in drinking water from some communities analyzed in our study exceed the maximum permissible limit of $50 \mathrm{mg} / \mathrm{L}$. In a study conducted in Mérida, Yucatán, Mexico, reported concentrations of 15.51-70.61 mg/L in water for human consumption. The authors studied the risk to the exposed population and found that infants have a higher risk than adults, therefore they suggested the implementation of strategies to control nitrate contamination sources and improve water quality (Rojas Fabro et al., 2015). In a review study, the presence of nitrates in water for human consumption was analyzed and it was found that the concentration of nitrates is higher in agricultural and livestock areas. These areas were

Table 4 - Genotypic and allelic frequencies in women exposed to nitrates in drinking water.

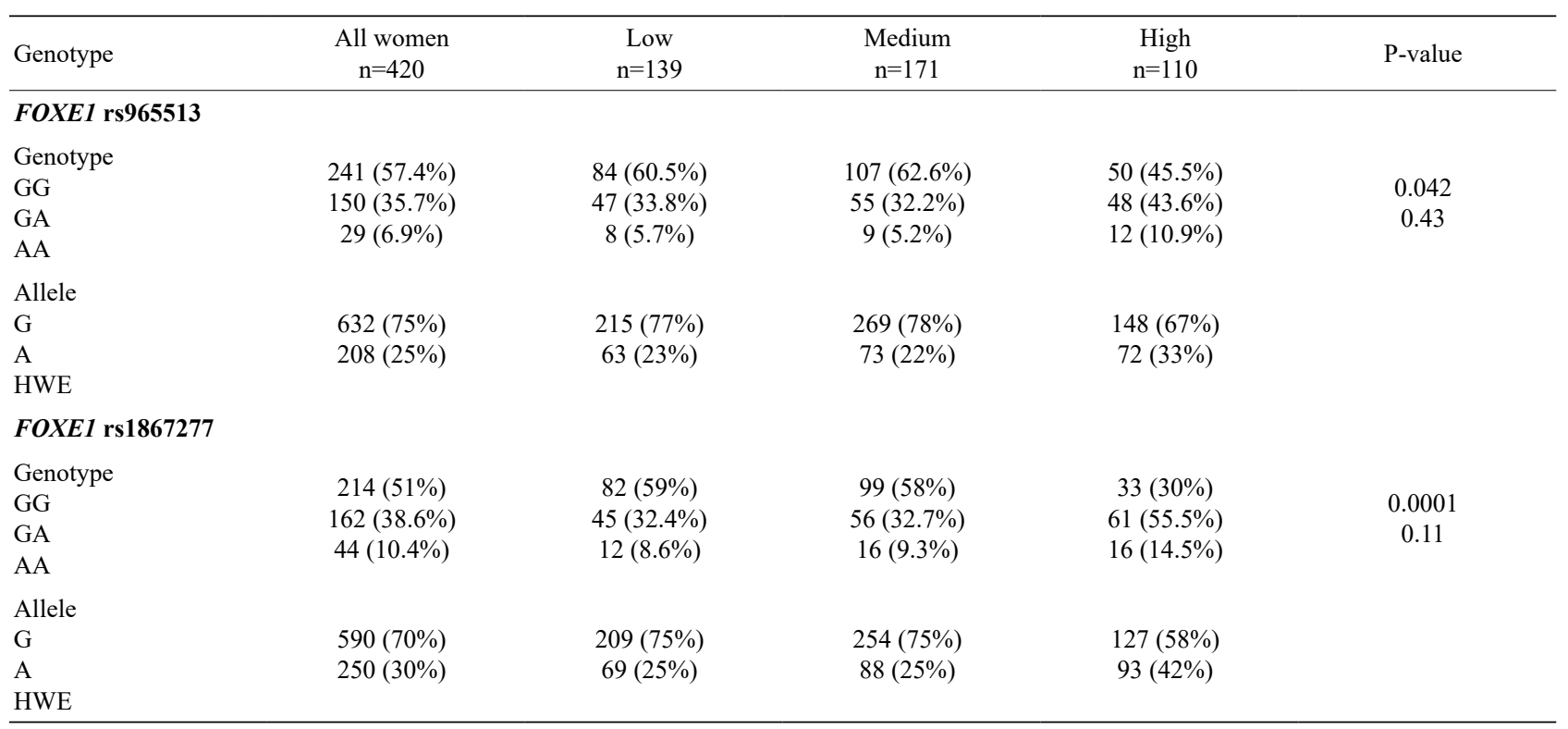

P-value corresponds to Chi squared test HWE $=$ Hardy-Weinberg Equilibrium 
A) FOXE1 rs 965513

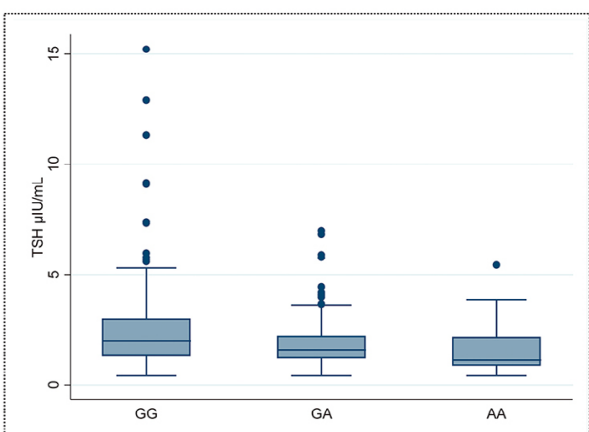

TSH $p=0.0001$

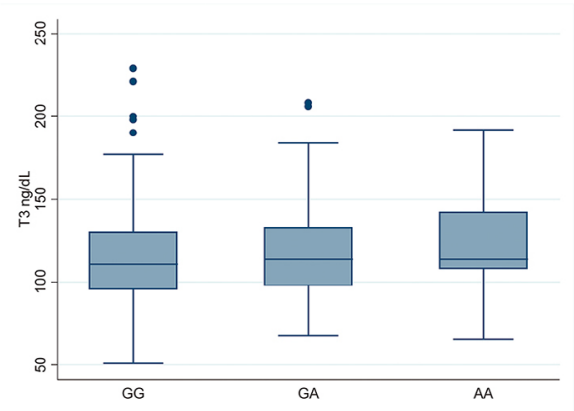

Total T3 p $=0.24$

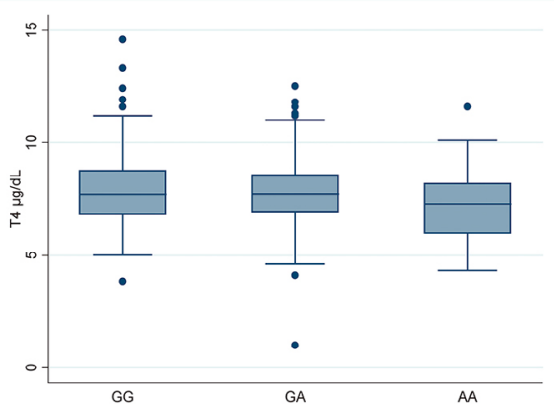

Total T4 $\mathrm{p}=0.17$
B) FOXE1 rs 1867277

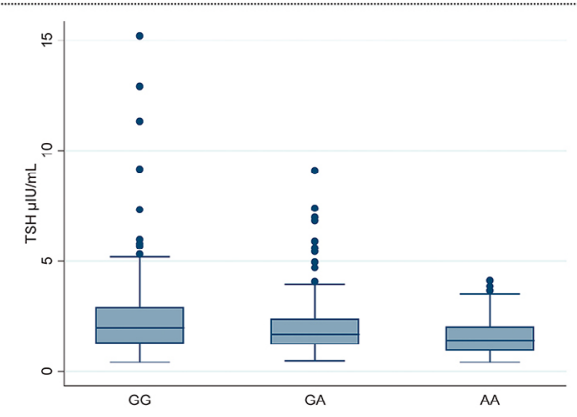

TSH $p=0.0054$

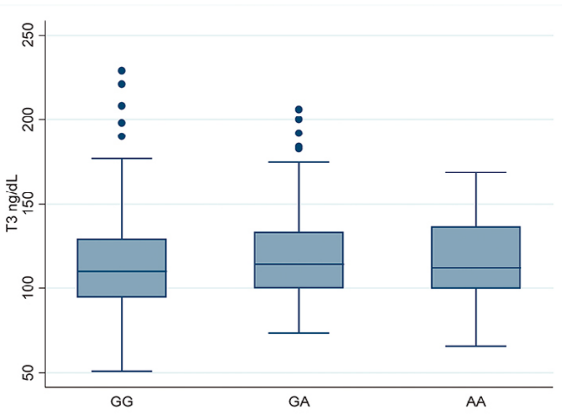

Total T3 $\mathrm{p}=0.25$

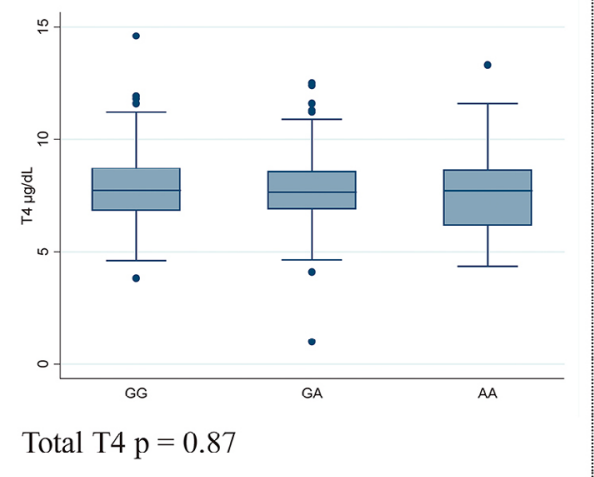

Figure 1 - THS levels according to FOXE1 genotypes. A) rs965513 polymorphism. B) rs1867277 polymorphism. P-values correspond to the KruskalWallis test.

Table 5 - Genotoxic damage in women exposed to nitrates in drinking water.

\begin{tabular}{|c|c|c|c|c|c|c|}
\hline Parameter & $\begin{array}{c}\text { All women } \\
n=420\end{array}$ & $\begin{array}{c}\text { Low } \\
\mathrm{n}=139\end{array}$ & $\begin{array}{c}\text { Medium } \\
\mathrm{n}=171\end{array}$ & $\begin{array}{l}\text { High } \\
\mathrm{n}=110\end{array}$ & Reference rank & P-value \\
\hline $\begin{array}{l}\text { Index of nuclear } \\
\text { division }\end{array}$ & $1.85(1.82-1.86)$ & $1.84(1.81-1.86)$ & 1.85 (1.83-1.87) & $1.85(1.78-1.87)$ & $1.3-2.2$ & 0.0896 \\
\hline Mononuclear cells \% & $15.5(12.7-18.2)$ & $16.9(13.9-19.4)$ & $15.8(12.9-17.9)^{\mathrm{a}}$ & $13(10.8-15.6)^{b, c}$ & - & $0.0001 *$ \\
\hline Binucleated cells \% & $34.9(29.7-39.4)$ & $38.4(34.6-40.1)$ & $32.6(27.3-38.4)^{\mathrm{a}}$ & $34.2(26.5-39.3)^{\mathrm{c}}$ & $30-60$ & $0.0001 *$ \\
\hline Multinucleated cells & $22(19-26)$ & $21(18-26)$ & $23(19-26)^{a}$ & $21.5(19-26)$ & - & 0.0711 \\
\hline Apoptosis cells \% & $15(11-19)$ & $16(11-21)$ & $15(12-19)$ & $13(11-19)$ & $0-7$ & 0.4990 \\
\hline Necrotic cells $\%$ & $11(8-16)$ & $12(9-16)$ & $11(8-16)$ & $11(8-18)$ & $0-9$ & 0.7126 \\
\hline Micronucleus \% & $38.9(35.6-45.6)$ & $35.2(31.6-38.7)$ & $41.8(37.1-47.7)^{\mathrm{a}}$ & $42.6(37.6-48.3)^{\mathrm{c}}$ & $0-30$ & $0.0001 *$ \\
\hline Cells with bridge $\%$ & $24(19-29)$ & $24(19-29)$ & $24(19-28)$ & $25.5(21-31)$ & $0-10$ & 0.0321 \\
\hline Cells with bubble \% & $25(19-31)$ & $25(19-34)$ & $23(18-28)^{a}$ & $26(21-34)$ & $0-5$ & $0.0021 *$ \\
\hline
\end{tabular}

Reference Rank was based on Fenech (2007) methodology.

P-value correspond to Kruskal Wallis test. * Significant differences

Significant differences in Dunn's test $(\mathrm{p}<0.05)$ : ${ }^{\mathrm{a}}$ exposure low-medium, ${ }^{\mathrm{b}}$ exposure low-high, ${ }^{\mathrm{c}}$ exposure medium-high. 
Table 6 - Multivariate analysis of the association between thyroid hormone, biomarkers and concentration of nitrates in drinking water.

\begin{tabular}{|c|c|c|c|c|c|c|c|c|c|c|c|c|c|c|c|}
\hline & \multicolumn{3}{|c|}{ TSH $\mu \mathrm{UI} / \mathrm{mL}$} & \multicolumn{3}{|c|}{ T4 ng/dL } & \multicolumn{3}{|c|}{ T4 free } & \multicolumn{3}{|c|}{ T3 pg/mL } & \multicolumn{3}{|c|}{$T 3$ free } \\
\hline & $\beta$ & SE & p-value & $\beta$ & SE & p-value & $\beta$ & $\mathrm{SE}$ & p-value & $\beta$ & $\mathrm{SE}$ & p-value & $\beta$ & $\mathrm{SE}$ & P-value \\
\hline Low exposure & 1 & & & 1 & & & 1 & & & 1 & & & 1 & & \\
\hline Medium exposure & 0.21 & 0.08 & $0.007^{*}$ & -0.07 & 0.02 & $0.008^{*}$ & -0.03 & 0.02 & 0.070 & 0.07 & 0.03 & $0.008^{*}$ & 0.12 & 0.03 & $0.0001 *$ \\
\hline High exposure & -0.01 & 0.08 & 0.833 & -0.03 & 0.03 & 0.298 & -0.0007 & 0.02 & 0.972 & 0.02 & 0.03 & 0.447 & -0.007 & 0.03 & 0.822 \\
\hline $\begin{array}{l}\text { Nitrite } \mu \mathrm{mol} / \mathrm{mL} \\
\text { blood }\end{array}$ & 0.02 & 0.03 & 0.500 & 0.002 & 0.01 & 0.843 & 0.006 & 0.008 & 0.433 & 0.001 & 0.01 & 0.882 & -0.007 & 0.01 & 0.571 \\
\hline $\begin{array}{l}\text { Nitrite } \mu \mathrm{mol} / \mathrm{mL} \\
\text { urine }\end{array}$ & -0.03 & 0.02 & 0.180 & -0.01 & 0.007 & $0.018^{*}$ & 0.013 & 0.005 & $0.012 *$ & 0.005 & 0.007 & 0.463 & 0.005 & 0.008 & 0.521 \\
\hline$\%<$ Methemoglobin & 0.002 & 0.04 & 0.966 & -0.005 & 0.02 & 0.716 & -0.007 & 0.01 & 0.542 & 0.02 & 0.02 & 0.274 & 0.005 & 0.02 & 0.770 \\
\hline Glucose mg/dL & 0.08 & 0.10 & 0.417 & -0.04 & 0.03 & 0.217 & -0.004 & 0.02 & 0.854 & -0.09 & 0.03 & $0.007 *$ & -0.07 & 0.04 & 0.080 \\
\hline Cholesterol mg/dL & -0.05 & 0.09 & 0.549 & -0.07 & 0.03 & $0.030^{*}$ & -0.04 & 0.02 & 0.092 & -0.03 & 0.03 & 0.311 & -0.05 & 0.03 & 0.125 \\
\hline $\mathrm{HDL} \mathrm{mg} / \mathrm{dL}$ & 0.02 & 0.07 & 0.725 & -0.005 & 0.02 & 0.851 & 0.006 & 0.02 & 0.761 & 0.03 & 0.03 & 0.264 & 0.008 & 0.03 & 0.788 \\
\hline LDL mg/dL & 0.12 & 0.09 & 0.182 & 0.02 & 0.03 & 0.451 & 0.05 & 0.02 & $0.021 *$ & 0.03 & 0.03 & 0.309 & -0.011 & 0.03 & 0.463 \\
\hline Triglyceride mg/dL & 0.06 & 0.06 & 0.317 & 0.002 & 0.02 & 0.893 & 0.008 & 0.01 & 0.581 & 0.07 & 0.02 & $0.0001^{*}$ & 0.018 & 0.02 & 0.419 \\
\hline $\begin{array}{l}\text { FOXE1 rs965513 } \\
\text { GG } \\
\text { GA } \\
\text { AA }\end{array}$ & $\begin{array}{c}1 \\
-0.17 \\
-0.40\end{array}$ & $\begin{array}{l}0.06 \\
0.13\end{array}$ & $\begin{array}{l}0.015^{*} \\
0.002^{*}\end{array}$ & $\begin{array}{c}1 \\
-0.03 \\
-0.11\end{array}$ & $\begin{array}{l}0.02 \\
0.04\end{array}$ & $\begin{array}{c}0.204 \\
0.017^{*}\end{array}$ & $\begin{array}{c}1 \\
-0.02 \\
-0.03\end{array}$ & $\begin{array}{l}0.01 \\
0.03\end{array}$ & $\begin{array}{l}0.258 \\
0.301\end{array}$ & $\begin{array}{c}1 \\
0.02 \\
0.09\end{array}$ & $\begin{array}{l}0.02 \\
0.05\end{array}$ & $\begin{array}{c}0.299 \\
0.039 *\end{array}$ & $\begin{array}{c}1 \\
0.03 \\
0.10\end{array}$ & $\begin{array}{l}0.02 \\
0.05\end{array}$ & $\begin{array}{c}0.278 \\
0.048^{*}\end{array}$ \\
\hline $\begin{array}{l}\text { FOXE1 rs } 1867277 \\
\text { GG } \\
\text { GA } \\
\text { AA }\end{array}$ & $\begin{array}{c}1 \\
-0.001 \\
-0.09\end{array}$ & $\begin{array}{l}0.07 \\
0.11\end{array}$ & $\begin{array}{l}0.984 \\
0.418\end{array}$ & $\begin{array}{c}1 \\
0.002 \\
0.01\end{array}$ & $\begin{array}{l}0.02 \\
0.04\end{array}$ & $\begin{array}{l}0.904 \\
0.751\end{array}$ & $\begin{array}{c}1 \\
0.02 \\
0.03\end{array}$ & $\begin{array}{l}0.02 \\
0.03\end{array}$ & $\begin{array}{l}0.100 \\
0.312\end{array}$ & $\begin{array}{c}1 \\
0.02 \\
0.03\end{array}$ & $\begin{array}{l}0.02 \\
0.04\end{array}$ & $\begin{array}{l}0.241 \\
0.418\end{array}$ & $\begin{array}{c}1 \\
0.006 \\
-0.02\end{array}$ & $\begin{array}{l}0.03 \\
0.04\end{array}$ & $\begin{array}{l}0.814 \\
0.611\end{array}$ \\
\hline $\begin{array}{l}\text { \% Binucleated cells } \\
\text { with MN }\end{array}$ & 0.0002 & 0.0004 & 0.605 & 0.0001 & 0.0001 & 0.643 & -0.0002 & 0.0001 & $0.034^{*}$ & 0.0001 & 0.0001 & 0.754 & -0.0001 & 0.0001 & 0.956 \\
\hline
\end{tabular}

TSH y nitrite were transformed to logarithmic scale.

Linear multivariate regression; adjusted by age, BMI, educational, drinking water, smoking current and alcohol consumption

SE standard error. * Significant difference 
designed as "nitrate vulnerable zones" and are subject to a special regulation included in the Codes of Good Agricultural Practice. The aforementioned study collects data since 1950, in different countries, and mentions that some European countries have carried out actions to recover aquifers and decrease the presence of nitrates in drinking water. However, other Asian and African countries report higher levels, between $40-100 \mathrm{mg} / \mathrm{L}$ of nitrates; and some agricultural wells show extremely high levels: up to $500 \mathrm{mg} / \mathrm{L}$ of nitrates. In these zones, levels of methemoglobinemia are monitored in the child population (Ward et al., 2018). The first effect associated with the consumption of nitrates in drinking water was methemoglobinemia in lactating children, and based on this finding, the permissible limits were determined to avoid acute effects. One of the most notable studies was the case of children in Gaza; this region contains very high levels of nitrates in the drinking water and $65.9 \%$ of children aged between 3 to 6 months had metHb $>5 \%$ and the reference level was 1.5\%-2\% (Abu Naser et al., 2007).

The ingested nitrate is metabolized to nitrite and NO, consequently metHb increases and the amount of oxygen available in the blood decreases; additionally, nitrite plasma levels increase, as well as its excretion in urine, with a linear relationship between the urinary nitrate excretion rate and plasma. In this study we found an increase in the percentage of metHb and nitrite in plasma and urine, and correlation between these parameters. In all cases the concentration increased according to the exposure doses. Our results agree with other studies, Bondonno et al. (2015) reported an increase in nitrite concentrations in plasma and urine as a result of exposure to nitrates; Kapil et al. (2018) found an increase in plasma nitrate after intake of dietary inorganic nitrate, the levels were higher in women than in men and were dependent on the oral microbiota. While Williams et al. (2020) found that the plasma nitrate concentration depends on the renal efficiency to excrete it to the urine; therefore, recirculation and clearance of nitrate depends on different factors. In contrast, metHb formation is constant in the organism, and to maintain a normal range $(<1.5 \%)$, endogenous enzymatic systems such as NADH-dependent cytochrome b5 reductase and NADPHdependent methemoglobin reductase are involved. It has been demonstrated that metHb values return to a basal state after 24 hours, but exposure to oxidizing agents, such as nitrate and its metabolites, accelerates the rate of metHb formation, exceeding the endogenous enzymatic systems and increasing its percentage in the blood (Thomas et al., 2019).

Regarding the biochemical parameters analyzed in this study, a significant increase was found in the concentrations of glucose, triglycerides, total, HDL and LDL cholesterol from the exposed groups. In this respect, Bahadoran et al. (2018) reported data from a 20-year cohort study, where they found an association between nitrate metabolites and the risk of developing metabolic syndrome $(\mathrm{OR}=1.7595 \% \mathrm{CI}=1.19-2.59)$ and type II diabetes $(\mathrm{HR}=2.43,95 \% \mathrm{CI}=1.45-4.05)$.

Meanwhile NO and its stable metabolites (nitrite and nitrate) have a dual role because they are related to normal and pathological processes. Furthermore, the endogenous production of NO is carried out by the isoforms of the nitric oxide synthase enzyme; however, it has not been possible to determine the endogenous and exogenous contribution of NO-nitrite-nitrate and its homeostatic balance to maintain the health of the organism. In another study, NO-nitritenitrate plasma levels were analyzed, and it was found that these are affected by aging, smoking habits, pregnancy, menopause, thyroid hormones and pathologies such as: type II diabetes, resistance to insulin, hypertension and kidney dysfunction (Bahadoran et al., 2019). However, it is important to determine the endogenous and exogenous contribution to the development of these pathologies. Additionally, an experimental study showed that long-term dietary nitrate and nitrite causes metabolic syndrome, endothelial dysfunction, and cardiovascular damage in mice (Kina-Tanada et al., 2017).

On the other hand, FOXE1 is a transcription factor that regulates the expression of the thyroglobulin (TG) and thyroid peroxidase (TPO) genes; the expression of both genes is essential to the synthesis of T3 and T4 hormones, and these are necessary for maintaining a differentiated state of the thyroid gland. In addition, thyroid hormones play an important role in different organs, where they participate in cell metabolism, growth, development and differentiation. Thyroid disorders related with nitrates in drinking water have been reported (Aschebrook-Kilfoy et al., 2012) one of them is SH, that is characterized by increased TSH levels and normal T3 and $\mathrm{T} 4$ levels. In the present work we found $8.3 \%$ of SH in the total population, and $11 \%$ in the medium exposure group ( $30 \mathrm{mg} / \mathrm{L}$ nitrates). In this regard, Modarelli and Ponzo (2019) reported $40.6 \%$ of $\mathrm{SH}$, many of the individuals consumed water from agricultural wells, where nitrate levels ranged between $24-83 \mathrm{mg} / \mathrm{L}$. We also found alterations in the levels of fT3, $\mathrm{T} 4$ and $\mathrm{fT} 4$, these associations are maintained in the multiple regression model and statistical significance is observed in the medium exposure group. Some authors have reported that alterations in thyroid hormones can lead to the development of thyroid cancer (Huang et al., 2017). Additionally, the rs965513 polymorphism of FOXE1 has been associated with sporadic and familial cases of thyroid cancer. Gudmundsson et al. (2009) report that the polymorphic allele (A) is associated with low TSH concentrations, also found that T3 and T4 are also modulated by the presence of polymorphisms. Our data agrees with these findings, we found that the presence of the A allele decreases TSH concentrations; this effect was also observed in the FOXE1 rs 1867277 polymorphism, suggesting that the thyroid alterations observed in the study population may be influenced by the environment (nitrates in drinking water) and by genetic factors (polymorphisms in the FOXE1 gene).

Finally, nitrates are metabolized to nitrite and NO, and this could generate RNS through the nitrosylation of cysteine residues in proteins, or via nitration reactions to form nitro adducts with fatty acids, proteins and nucleosides, generating genotoxic damage. Regarding the genotoxic damage in lymphocytes, we found a high percentage of binucleated cells with micronuclei, binucleated cells with nucleoplasmic bridges and binucleated cells with bubble protrusion, in medium and high exposure groups. These results agree with findings reported by Andreassi et al. (2001) they observed a higher frequency of micronucleated lymphocytes and suggest possible chromosome alterations in humans exposed to chronic long-term nitrate therapy, and van Breda et al. (2019) reported 
the formation of $\mathrm{N}$-nitroso compounds in faecal water caused by the consumption of nitrates in drinking water, vegetables, and cured meat. Increasing the excretion of nitrate in urine and the concentration of $\mathrm{N}$-nitroso compounds during the exposure time. The genotoxic damage of the metabolites was analyzed by comet assay, and an increase in DNA damage was observed in $\mathrm{CaCo} 2$ cells.

Finally, the effects of environmental exposure to nitrates have been reviewed previously (Edwards and Hamlin, 2018) and concluded that nitrates follow a nonmonotonic dose-response curve. Thus, it is important to understand the physiology of nitrate exposure under different scenarios as acute and subacute studies at low doses cause hormonal alterations, subchronic studies at moderate doses cause an increase in steroid hormones, and very high doses can result in cytotoxic effects; however, it is necessary to characterize the effects in different environmental conditions and in various populations. In conclusion our results showed that nitrates concentrations in drinking water are above the permissible limit and an increase in the percentage of metHb, nitrite in blood plasma and urine were found. Also, metabolic and hormonal alterations in glucose, total cholesterol, LDL, triglycerides, TSH fT3, T4T and fT4, but FOXE1 (rs965513, rs1867277) genotypes were associated with a decrease in TSH, suggesting a gene-environment interaction. A high percentage of the samples had micronuclei in binucleated cells. Therefore, the exposure to nitrates in drinking water have a negative effect on human health in chronically exposed women.

\section{Acknowledgements}

This study was supported by a grant from Consejo Nacional de Ciencia y Tecnología (CONACYT-2014-01241713) to RPM. DDGE had a fellowship from CONACYT (CVU 391248, number 379711). The authors thank Sandra González Nieto, Cesar Fraire Galindo and Cristo Omar Puente Valenzuela for their technical assistance. The thyroid hormones were quantified in the Instituto de Ciencia y Medicina Genomica under the supervision of Rafael Arguello Astorga and Alejandra Méndez Hernández.

\section{Conflict of Interest}

The authors declare that there is no conflict of interest that could be perceived as prejudicial to the impartiality of the reported research.

\section{Author contributions}

DDGE performed experimental work and help writing the results; EYCR participated in the design of the study and sampling; HMM performed the multivariate models and statistical analyses; MFGD participated in the analysis of biochemical parameters and interpretation of results; GGGV and JDS performed the analysis in water and urine samples; AGZ and ERS participated in curating the database and conducted the statistical analyses, edited images and participated in writing and discussion of the manuscript; RPM designed the study, participated in the implementation of techniques and wrote the manuscript. All authors read and approved the final version.

\section{References}

Abu Naser AA, Ghbn N and Khoudary R (2007) Relation of nitrate contamination of groundwater with methaemoglobin level among infants in Gaza. East Mediterr Health J 13:994-1004.

Andreassi MG, Picano E, Del Ry S, Botto N, Colombo MG and Giannessi D (2001) Chronic long-term nitrate therapy: possible cytogenetic effect in humans? Mutagenesis 16:517-521.

Aschebrook-Kilfoy B, Ward MH, Dave BJ, Smith SM, Weisenburger DD and Chiu BC (2012) Dietary nitrate and nitrite intake and risk of non-Hodgkin lymphoma. Leuk Lymphoma 54:945-950.

Bahadoran Z, Mirmiran P, Jeddi S, Carlström M, Azizi F and Ghasemi A (2019) Circulating markers of nitric oxide homeostasis and cardiometabolic diseases: insights from population-based studies. Free Radic Res 53:359-376

Bahadoran Z, Mirmiran P, Jeddi S, Momenan AA, Azizi F and Ghasemi A (2018) The nitrate-nitrite-nitric oxide pathway: Findings from 20 years of the Tehran lipid and glucose study. Int J Endocrinol Metab 16:e84775.

Bondonno CP, Liu H, Croft KD, Ward NC, Puddey IB and Woodman RJ (2015) Short-term effects of a high nitrate diet on nitrate metabolism in healthy individuals. Nutrients 7:1906-1915.

Calleros Rincón EY, Alarcón Herrera MT, Morán Martínez J, Cueto Wong JA, Pérez-Morales R and Sanin LH (2012) Caracterización de una zona contaminada por nitratos y su impacto en la salud humana. In: Cedillo LA, Roble FKC (eds). Género, ambiente y contaminación por sustancias químicas. Secretaría de Medio Ambiente y Recursos Naturales, Instituto Nacional de Ecología, México D.F., pp 35-54.

Cengiz MF and Bilgin AK (2016) Determination of major sodium iodide symporter (NIS) inhibitors in drinking waters using ion chromatography with conductivity detector. J Pharm Biomed Anal 120:190-197.

Chen YH and Zhang YQ (2018) Exploration of the association between $F O X E 1$ gene polymorphism and differentiated thyroid cancer: a meta-analysis. BMC Med Genet 19:83.

DeMartino A, Kim-Shapiro DB, Patel RP and Gladwin MT (2019) Nitrite and nitrate chemical biology and signaling. British J Pharmacol 176:228-245.

Donoso R and Cortés S (2018) Exposure to nitrates in drinking water and its association with thyroid gland dysfunction. Rev Med Chile 146:223-231.

Edwards T M and Hamlin HJ (2018) Reproductive endocrinology of environmental nitrate. Gen Comp Endocrinol 265:31-40.

Fenech M (2007) Cytokinesis-block micronucleus cytome assay. Nat Protoc 2:1084-1104.

Friedewald WT, Levy RI and Fredrickson DS (1972) Estimation of the concentration of low-density lipoprotein cholesterol in plasma, without use of the preparative ultracentrifuge. Clin Chem 18:499-502.

Gudmundsson J, Sulem P, Gudbjartsson DF, Jonasson JG, Sigurdsson A and Bergthorsson J (2009) Common variants on 9q22.33 and $14 \mathrm{q} 13.3$ predispose to thyroid cancer in European populations. Nature Genet 41:460-464.

Hallinger DR, Murr AS, Buckalew AR, Simmons SO, Stoker TE and Lawsa SC (2017) Development of a screening approach to detect thyroid disrupting chemicals that inhibit the human sodium iodide symporter (NIS). Toxicol in Vitro 40:66-78.

Huang H, Rusiecki J, Zhao N, Chen Y, Ma S and Yu H (2017) Thyroid-stimulating hormone, thyroid hormones, and risk of papillary thyroid cancer: A nested case-control study. Cancer Epidemiol Biomarkers Prev 26:1209-1218.

Johnson CJ, Bonrud P, Dosch TL, Kilness AW, Senger KA and Busch D (1987) Fatal outcome of methemoglobinemia in an infant. JAMA 257:2796-2797. 
Kapil V, Rathod KS, Khambata RS, Bahra M, Velmurugan S and Purba A (2018) Sex differences in the nitrate-nitrite-NO• pathway: Role of oral nitrate-reducing bacteria. Free Radic Biol Med 126:113-121.

Karwowska M and Kononiuk A (2020) Nitrates/Nitrites in food risk for nitrosative stress and benefits. Antioxidants 9:241.

Kina-Tanada M, Sakanashi M, Tanimoto A, Kaname T, Matsuzaki $\mathrm{T}$ and Noguchi K (2017) Long-term dietary nitrite and nitrate deficiency causes the metabolic syndrome, endothelial dysfunction and cardiovascular death in mice. Diabetologia 60:1138-151.

Lundberg JO, Carlström M and Weitzberg E (2018) Metabolic effects of dietary nitrate in health and disease. Cell Metab 28:9-22.

Mendieta-Zerón H, Jiménez-Rosales A, Pérez-Amado CJ and Jiménez-Morales S (2017) FOXE1 Mutation screening in a case with cleft lip, hypothyroidism, and thyroid carcinoma: A new syndrome? Case Rep Genet 2017:6390545.

Modarelli MF and Ponzo O (2019) Relationship of subclinical hypothyroidism and goiter with the origin of water consumed by a population of the Buenos Aires suburbs. Medicina (B Aires) 79:11-19.

Moshage H, Kok B, Huizenga JR and Jansen PL (1995). Nitrite and nitrate determina- tions in plasma: a critical evaluation. Clin Chem 41:892-896.

Ombreta P, Seyedsalehi M and Masssabo M (2018) Probabilistic risk assessment of nitrate groundwater contamination from greenhouses in Albenga plain (Liguria, Italy) using lysimeters. Sci Total Environ 634:427-438.

Rocha BS, Gago B. Barbosa RM, Lundberg JO, Radi R and Laranjinha J (2012) Intragastric nitration by dietary nitrite: Implications for modulation of protein and lipid signaling. Free Radical Biol Med 52:693-698.

Rojas Fabro AY, Pacheco Ávila JG, Esteller Alberich MB, Cabrera Sansores SA and Camargo-Valero MA(2015) Spatial distribution of nitrate health risk associated with groundwater use as drinking water in Merida, Mexico. Appl Geography 65:49-59.

Sakata M, Yoshida A and Haga M (1982). Methemoglobin in blood as determined by double-wavelength spectrophotometry. Clin Chem 28:508-511.
Stivaktakis P, Vlastos D, Giannakopoulos E and Matthopoulos DP (2010) Differential micronuclei induction in human lymphocyte cultures by imidacloprid in the presence of potassium nitrate. Sci World J 10:80-89.

Thomas SM, Cherian JJ, Thampi SP and George B (2019) Acquired Methemoglobinemia- An Overview. Ind J Pharmacy Pract 12:270-277.

van Breda SG, Mathijs K, Sági-Kiss V, Kuhnle GG, van der Veer B and Jones RR (2019) Impact of high drinking water nitrate levels on the endogenous formation of apparent $\mathrm{N}$-nitroso compounds in combination with meat intake in healthy volunteers. Environ Health 18:87.

Ward MH, Jones RR, Brender JD, de Kok TM, Weyer PJ, Nolan BT, Villanueva CM and van Breda SG (2018) Drinking water nitrate and human health: An updated review. Int J Environ Res Pub Health 15:1557.

Williams JK, Smallwood MJ, Benjamin N, D'Souza RJ, Shore AC, Winyard PG and M Gilchrist (2020) Renal nitrate clearance in chronic kidney disease. Nitric Oxide 97:16-19.

\section{Internet Resources}

National Water Commission, CONAGUA-Mexico, https://sigagis conagua.gob.mx/gas1/sections/Edos/durango/durango.html (acessed 04 September 2019).

Official Mexican standard, NOM-127-SSA1-1994, Environmental health, water for human use and consumption-permissible limits of quality and treatments to which water must be submitted for its potabilization, http://www.salud.gob.mx/ unidades/cdi/nom/127ssa14.html (acessed 04 September 2019).

World Health Organization, Guidelines for drinking water quality (2011), http://www.who.int/water_sanitation_health/waterquality/guidelines/en/ (September 4 , 2019).

Associate Editor: Mara Hutz

License information: This is an open-access article distributed under the terms of the Creative Commons Attribution License (type CC-BY), which permits unrestricted use, distribution and reproduction in any medium, provided the original article is properly cited. 